Hewit, L. F. (1951). J. gen. Microbiol. 5, 287-292.

\title{
Cell Structure of Corynebacterium diphtheriae
}

\author{
By L. F. HEWITT \\ Serum Research Institute (Medical Research Council), Carshalton, Surrey
}

\begin{abstract}
SUMMARY: When examined by phase-contrast microscopy living diphtheria bacilli generally appear fairly transparent. They are sometimes unicellular but are frequently divided into compartments by readily visible cross-septa. In gravis and mitis strains the cross septa are usually few in number and the compartments long, but in intermedius strains there are often many cross-septa, and the organism may resemble a chain of cocci fused together. Club-shaped cells with swellings are seen in untreated living cultures as in fixed and stained preparations of killed bacteria, and occasionally branched forms are encountered. Undivided filaments sometimes occur in magnesiumdeficient cultures, whilst in magnesium-rich cultures cells with numerous cross-septa are scanty. The presence of magnesium salts has some protective effect against the growth-inhibition produced by beryllium salts. In cultures containing selenite or tellurite the bacteria become red or black, granules containing selenium and tellurium occur and areas resembling chromatinic structures may be seen.
\end{abstract}

The recorded morphology of the diphtheria bacillus is based mainly on examination of killed organisms fixed and stained by conventional methods, but recently there has been considerable development of new fixing and staining procedures (Badian, 1933; Piekarski, 1937; Stille, 1937; Robinow, 1942; Klieneberger-Nobel, 1945; Knaysi, 1946; Mudd \& Smith, 1950; Smith, 1950). It is of interest to determine how much the appearances seen are artefacts and how they correspond to the morphology of living untreated cells.

The occurrence of club-shaped swellings led Lehmann \& Neumann (1899) to use the name Corynebacterium which is still generally accepted (Topley \& Wilson, 1946; Bergey, 1948), although by no means all of the organisms in diphtheria cultures show swellings when stained. If, as suggested by Bisset $(1949,1950)$, the swellings are due to artefacts caused by fixing and staining, and if diphtheria bacteria are clearly rod-shaped or coccal in the natural untreated state, some alteration in nomenclature and classification would seem desirable.

Since the microscopy of living cells using phase-contrast microscopy is relatively recent, it is not yet certain what cellular structures apart from external shape will be visible in different preparations, nor what methods of preparation will be most effective.

\section{MATERIALS AND METHODS}

The diphtheria strains examined were those serologically typed previously (Hewitt, 1947) and recently isolated strains. The culture media used for their propagation were Loeffler serum, serum agar and blood agar plates, and various special broths which will be mentioned later. Most of the preparations examined were made by modifications of a slide-cell technique (Fleming, Voureka, Kramer \& Hughes, 1950; Pulvertaft \& Weston, 1950). Delicate organisms may be damaged by subjection to prolonged drying or warming. In order to avoid 
such damage moist smears of bacteria on cover-slips should not be allowed to remain exposed to air for long and if mounted in melted media, the temperature should be allowed to fall before the culture is covered. The refractive index of $30 \%$ gelatine, as well as its melting-point, make it superior to agar for many purposes, and in most cases good results were obtained with gelatine. All the preparations were examined using the $2 \mathrm{~mm}$. phase-contrast objective of Cooke, Troughton \& Simms.

\section{OBSERVATIONS}

The cytoplasm of living cells of $C$. diphtheriae in the preparations described above, is often almost transparent, and cross-septa dividing the cells into compartments are plainly visible without staining. In the gravis and mitis strains depicted in Pl. 1, figs. 1-5, cells containing from one to three cross-septa are seen. Figs. 1 and 2 depict the same field at a $2 \mathrm{hr}$. interval; in that time an extra cross-septum has appeared in a cell in the centre of the field. Division of the cell occurs at the cross-septum but no previous constriction of the cell at this point has been observed. The two daughter cells suddenly bend apart giving rise to the familiar 'chinese letter' formation. For comparison there are shown in Pl. 1, figs. 6, 7, two preparations of killed diphtheria bacilli which were fixed in osmium tetroxide vapour and $70 \%$ ethanol, mordanted in $10 \%$ tannic acid and stained with crystal violet, a procedure which is used to demonstrate cell walls (Gutstein, 1924). The close similarity between the appearance of living cells examined by phase-contrast microscopy and of the stained preparations is very striking, in contrast to the very different appearance of preparations made by conventional routine heat fixation and staining methods.

Some strains in particular show, in addition to simple almost rod-like forms, club-shapes and swollen-ended organisms (Pl. 1, fig. 3; Pl. 2, figs. 16-19). Occasional indisputably branched forms are encountered, as can be seen clearly in Pl. 2, figs. 8-13. Nuclear structures are not generally visible in cultures grown in ordinary media but some detailed structure may be discerned in Pl. 3, fig. 32.

Intermedius strains are very different in appearance from gravis or mitis strains. Numerous cross-septa divide the cells into circular or oval coccus-like compartments, each of which can be shown by appropriate staining methods to contain a chromatinic body. In Pl. 2, fig. 14, is shown a phase-contrast photograph of an intermedius strain, and in Pl. 2, fig. 15, the same strain fixed in osmium tetroxide vapour and $70 \%$ ethanol, heated with $\mathrm{N}-\mathrm{HCl}$ and stained with dilute Giemsa solution (Robinow, 1942). It is evident that each cellular compartment is bounded by cell walls and contains a nuclear structure. The typically barred appearance of intermedius strains stained by conventional routine methods is evidently due to this multi-cellular structure and the deeper staining of the nuclear material in the separate compartments. In some intermedius cultures organisms are seen in which a cross-septum has formed across the widest part of the cellular compartment (Pl. 2, figs. 16, 17).

Diagrammatic representations of typical forms of living diphtheria bacilli are shown in Fig. 1. In $k$ are shown the cell walls of an intermedius strain and 
in $l$ the nuclear material in the cell compartments as revealed by the Giemsa staining method just mentioned.

Webb (1948) described the effect of magnesium deficiency in inhibiting celldivision of several species of Gram-positive bacteria. In the case of $C$. diphtheriae magnesium deficiency leads to restriction or even complete inhibition of growth, and occasionally filamentous forms are seen. Pl. 3, fig. 29, is a photograph of a gravis strain grown in a magnesium-deficient broth. Cross-septa
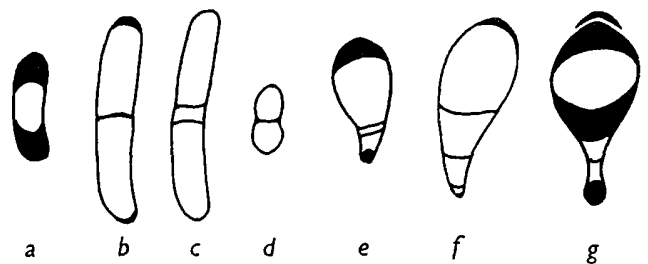

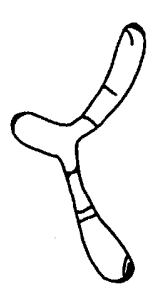

$h$

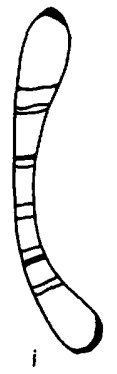

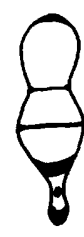
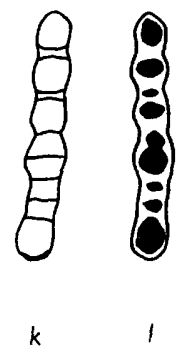

Fig. 1. Typical cell forms of $C$. diphtheriae. (All represent phase-contrast appearances of living cells except $l$ which is a stained preparation after fixation with osmic acid and hydrolysis with acid.)

have formed, but final rupture of the cells has not occurred and filaments are formed. In Pl. 3, fig. 30, is shown the same strain grown at the same time in the same broth to which $0.1 \%$ of magnesium sulphate had been added. No crosssepta are visible and the short cells possess more highly refractile areas at the poles, perhaps due to accumulation of magnesium nucleic acid complexes. Another example of filamentous forms of $C$. diphtheriae grown in magnesiumdeficient media is seen in $\mathrm{Pl}$. 3, fig. 31. In some gravis strains magnesium deficiency leads to the appearance of numerous cross-septa in the cells so that they resemble intermedius strains.

Beryllium salts in a concentration of more than about $0.004 \%$ inhibit the growth of $C$. diphtheriae, some strains being more sensitive than others. In the presence of a large excess of magnesium salts $(1 \%)$, this inhibition may be partly reversed, suggesting the possibility that beryllium may be inhibitory to growth by virtue of competitive antagonism to magnesium which is needed for cellular enzymic processes.

The reduction of tellurite by diphtheria bacilli is well known (Conradi \& Troch, 1912), and in media containing selenite colonies of $C$. diphtheriae become scarlet-red in colour owing to the production of selenium (Hewitt, 1947). The black or grey cells of $C$. diphtheriae grown in tellurite media possess some 
unusual forms; the living bacteria appear curved and are difficult to photograph. Highly refractile cellular structures are seen and frequently there are pairs of small spots in each cellular compartment (Pl. 2, figs. 20-25). The spots are of high refractive index and sometimes appear light by phase-contrast microscopy owing to their very highly refractile nature. Some of the grotesque forms seen are represented diagrammatically in Fig. 2. Diphtheria bacilli grown in selenite media also have highly refractile patches as seen in Pl. 3, figs. 26-28. It seems that the elementary tellurium and selenium when formed by cellular reduction processes may be deposited locally in the cell, possibly in the region of nuclear structures.

The appearance of living cells of a few different corynebacteria are shown in Pl. 3, figs. 33-38. Included are C. pyogenes, C. hofmannii, a diphtheroid, and C. fascians, a plant infective agent (kindly supplied by Dr S. E. Jacobs).

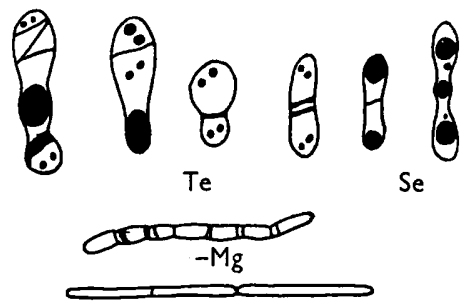

Fig. 2. C. diphtheriae; living cells grown in media containing tellurite or selenite, and in magnesium-deficient broth.

\section{DISCUSSION}

The pleomorphism of $C$. diphtheriae is very obvious when living cells are examined by phase-contrast microscopy. Small oval bacillary forms, long segmented bacteria and occasionally branched forms are seen. Organisms with club-shapes and polar swellings occur and justify their nomenclature as corynebacteria. Since the club-shapes are seen in living cultures they are not artefacts due to fixing and staining. In many culture media the relatively uniform refractivity and transparency of the cells make easily visible the crosssepta which are frequently present and divide the cells into two or more compartments. In the case of mitis and gravis strains there are generally few cross-septa and the compartments are long, but in intermedius types there are numerous almost circular compartments. This segmentation accounts for the characteristic barred appearance of intermedius strains, since the cells contain many cross-septa and they often resemble a chain of fused cocci. The external shape is a series of bulges, each bulge representing a single cellular compartment which by appropriate fixing and staining methods can be shown to contain chromatinic material. Presumably each cellular compartment on segmentation contains a complete genetic structure for the transmission of the characteristics of the strain. Although similar in fermentation reactions, intermedius strains can be differentiated from those of the mitis group, not only by their appearance when stained but also by serological methods (Hewitt, 1947). The segmented appearance of the living cells provides one more piece of evidence that the 
differentiation into intermedius and mitis groups is firmly based on definite cytological differences.

Shrinkage during heat-fixation alters considerably the appearance of $C$. diphtheriae stained by routine methods, but there is a very close similarity in the appearance of the cell walls and cross-septa in living cells and in stained preparations fixed by osmic acid and mordanted with tannic acid.

A most important factor in the morphology of bacteria is the composition of the culture medium. Normally multiplication of $C$. diphtheriae occurs by division at the position of the cross-septa, the daughter cells bending apart, ultimately forming a complex group of adjacent cells which readily entrain other organisms, rendering single-cell culture and isolation very difficult. As reported by Webb (1948) in the case of other organisms, magnesium deficiency in the culture medium interferes with cell division of $C$. diphtheriae and undivided bacteria with many cross-septa may be found. Some evidence was obtained of mutual antagonism between magnesium and beryllium salts and some reversal of the toxic effect of beryllium by a large excess of magnesium salts was observed.

The black and red colour assumed by diphtheria bacilli grown in tellurite and selenite media respectively is due to deposition of the elements in defined localities in the cells and there appears to be replication of these deposits in each segment of the cell. It appears possible that these depositions occur at the site of the nuclear structures of the cell compartments and the pairs of refractile spots seen are similar to the pairs of chromatinic structures reported by Robinow (1942) in spores of $B$. mycoides. Further investigation on these points is necessary, but it seems certain that phase-contrast microscopy, combined with variation in culture media and with other chemical treatments, is likely to contribute considerably in the development of bacterial cytology.

\section{REFERENCES}

Badian, J. (1933). Eine cytologische Untersuchung über das Chromatin und den Entwicklungszyklus der Bakterien. Arch. Mikrobiol. 4, 409.

Bergey's Manual of Determinative Bacteriology (1948), 6th ed., ed. by Breed, R. S., Murray, E. G. D. \& Hitchens, A. P. Baltimore: Williams and Wilkins.

BIsset, K. A. (1949). Observations upon the cytology of Corynebacteria and Mycobacteria. J. gen. Microbiol. 3, 93.

Bisset, K. A. (1950). The Cytology and Life-History of Bacteria. Edinburgh : Livingstone.

Conradi, H. \& Troch, P. (1912). Ein Verfahren zur Nachweis der Difteriebazillen. Münch. med. Wschr. 59, 1652.

Fleming, A., Voureka, A., Kramer, J. R. H. \& Hughes, W. H. (1950). The morphology and motility of Proteus vulgaris and other organisms cultured in the presence of penicillin. J. gen. Microbiol. 4, 247.

Gútstein, M. (1924). Über die Färbssische Darstellung der Bakterienektoplasmas. Zbl. Bakt. (1 Abt. Orig.), 93, 233.

Hewit, L. F. (1947). Serological typing of C. diphtheriae. Brit. J. exp. Path. 28, 338.

Klieneberger-Nobel, E. (1945). Changes in the nuclear structure of bacteria, particularly during spore formation. J. Hyg., Camb., 44, 99.

KnaYsi, G. (1946). Elements of Bacterial Cytology. Cornell: Comstock. 
Lehmann, K. B. \& Neumann, R. O. (1899). Atlas und Grundriss der Bakteriologie, 2nd edn, Teil 2, p. 371, München: Lehmann.

Mudd, S. \& SmIth, A. G. (1950). Electron and light microscopic studies of bacterial nuclei. I. J. Bact. 59, 561 .

Piekarski, G. (1937). Cytologische Untersuchungen an Paratyphus und Colibakterien. Arch. Mikrobiol. 8, 428.

Pulvertaft, R. J. V. \& Weston, R. McV. (1950). Phase-contrast cinemicrography. J. Path. Bact. 62, 132.

Robinow, C. F. (1942). A study of the nuclear apparatus of bacteria. Proc. Roy. Soc. B, 130, 299.

Sмiтн, A. G. (1950). Electron and light microscopic studies of bacterial nuclei. II. J. Bact. 59, 575.

Stille, B. (1937). Cytologische Untersuchungen an Bakterien mit Hilfe der Feulgenschen Nuklealreaktion. Arch. Mikrobiol. 8, 125.

WeBB, W. (1948). The influence of magnesium on cell division. I. The growth of Clostridium welchii in complex media deficient in magnesium. J. gen. Microbiol. $2,275$.

Topley \& Wilson's Principles of Bacteriology and Immunity (1946). 3rd edn. WiLson, G. S. \& Mrues, A. A. London: Arnold.

\section{EXPLANATION OF PLATES}

All the photographs are of living cells of $C$. diphtheriae examined hy phase-contrast microscopy unless otherwise stated.

\section{Plate 1}

Figs. 1, 2. Same field at $2 \mathrm{hr}$. interval showing formation of new cross-septum in central cell in Fig. $2 ; \times 3500$.

Fig. 3. Long forms; $\times 3500$.

Figs. 4, 5. Transparent cells showing cross-septa; $\times \mathbf{3 5 0 0}$.

Figs. 6, 7. Stained preparations. Fixed with osmic acid and $70 \%$ ethanol, treated with $10 \%$ tannic acid for $30 \mathrm{~min}$. and stained with crystal violet; $\times 3500$. Note similarity to living cells in other figures.

Figs. 8-13. Branched forms; $\times \mathbf{3 5 0 0}$.

\section{Plate 2}

Fig. 14. Intermedius strain showing multiple cross-septa; $\times 3500$.

Fig. 15. Intermedius strain stained with Giemsa stain after fixation with osmic acid and ethanol and hydrolysis with $\mathrm{N}-\mathrm{HCl}$ showing chromatinic structures in segments of cells between cross-septa; $\times 3500$.

Figs. 16, 17. 'Violin' shapes with cross-septa across wide part of cells; $\times 1800$.

Figs. 18, 19. Swollen and club forms; $\times 1800$.

Figs. 20-25. Living cells grown on tellurite-blood agar plates showing tellurium granules and cellular structure; $\times 3500$.

Figs. 26-28. Living cells grown on selenite-blood agar plates showing cellular structure; $\times 3500$.

\section{Plate 3}

Fig. 29. Cells grown in magnesium-deficient broth showing filaments; $\times 3500$.

Fig. 30. Same strain as Fig. 29 and grown in same broth with $0 \cdot 1 \% \mathrm{MgSO}_{4}$ added. Note short bacteria with polar refractile material but no cross-septa; $\times 3500$.

Fig. 31. Gravis strain from magnesium-deficient broth showing filament with cross-septa; $\times 3500$.

Fig. 32. Internal structure visible in long form; $\times \mathbf{3 5 0 0}$.

Figs. 33, 36. C. hofmannii (C. pseudodiphtheriticum); $\times 3500$.

Fig. 34. C. pyogenes; $\times 3500$.

Fig. 35. A diphtheroid; $\times 3500$.

Figs. 37, 38. C. fascians; $\times 3500$.

(Received 14 June 1950) 
Journal of General Microbiology, Vol. 5, No. 2

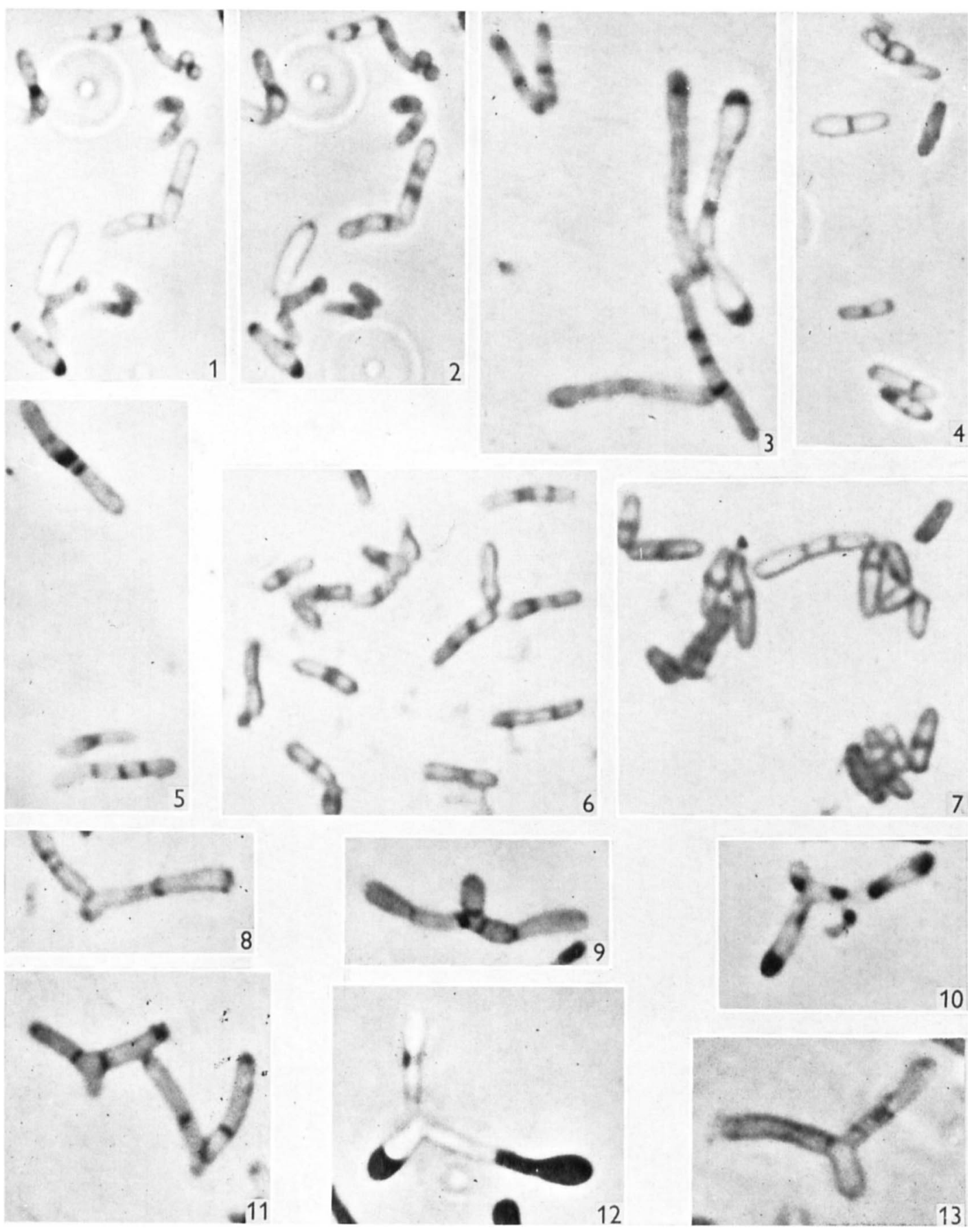

L. F. Hewite-Cell structure of C. Diphthertak. Plate 1 
Journal of General Microbiology, Vol. 5, No. 2
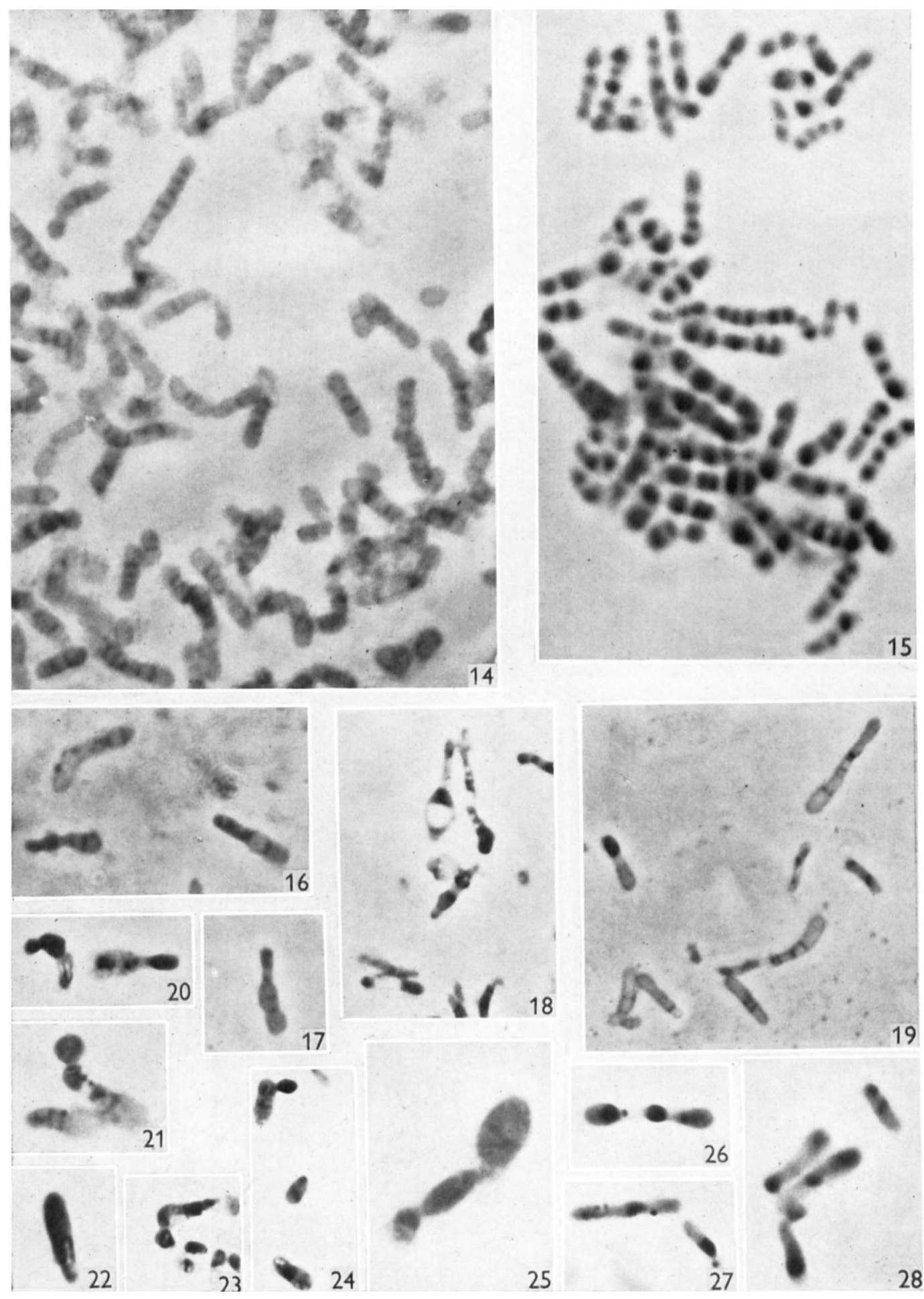

L. F. Hewitt-Cell structure of C. Diphtheriae. Plate 2 
Journal of General Microbiology, Vol. 5, No. 2
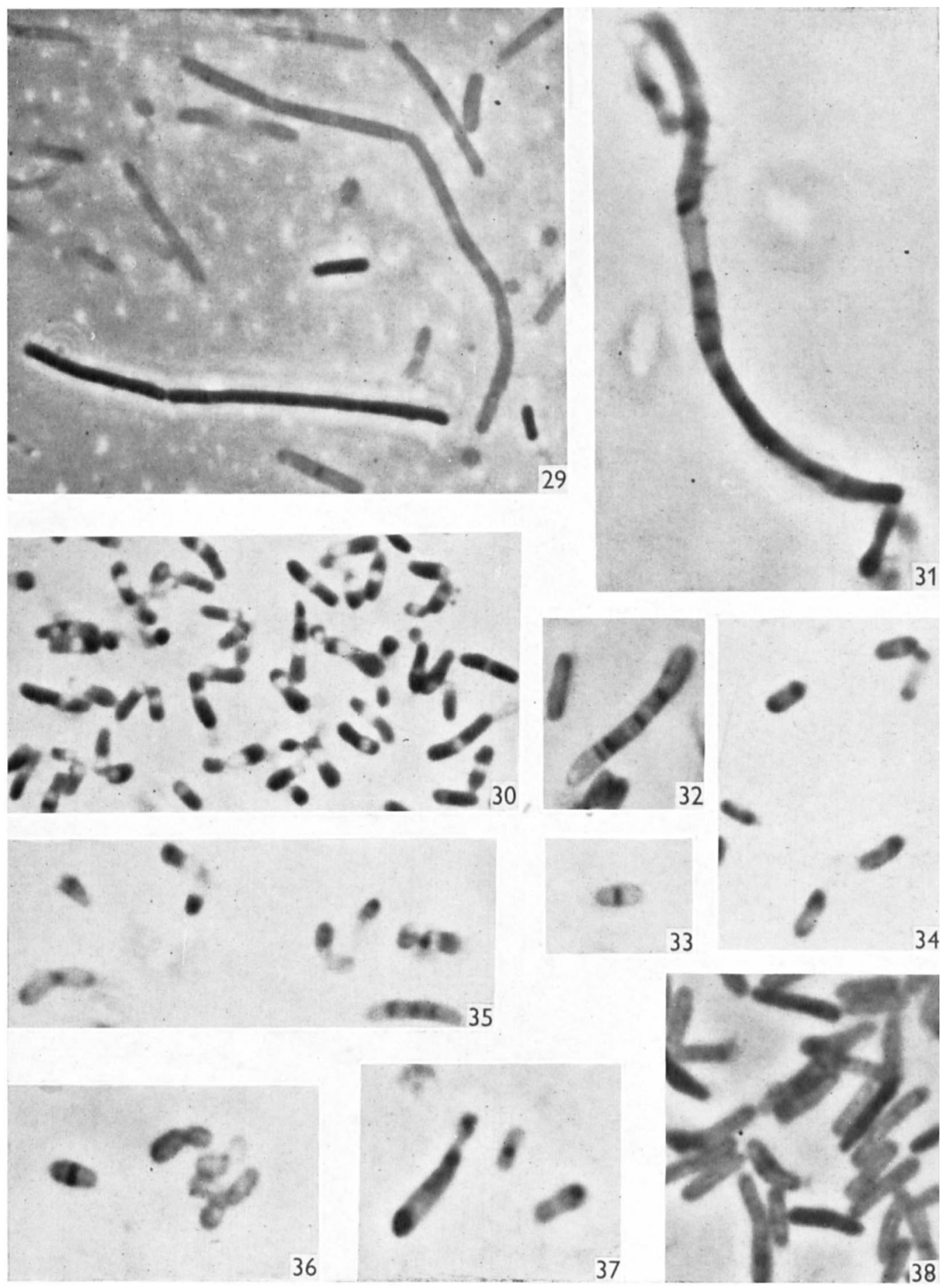

L. F. Hewitt-Cell structure of C. piphtheriae. Plate 3 